\title{
Plotinus on Transmigration: a Reconsideration ${ }^{1}$
}

\author{
Giannis Stamatellos
}

The aim of this paper is to reconsider Plotinus' account of transmigration in the light of his dual-aspect theory of the soul. It is argued that transmigration is discussed in the Enneads only in relation to the lower perceptible part of the soul. The higher intelligible part of the soul remains undescended and uninvolved in any kind of transmigration. Plotinus' treatment of transmigration also aims at emphasizing the soul's higher life of virtue. The noble soul concentrates on its higher intelligible part in constant contemplation of the Forms without being affected by its lower perceptible part and therefore transmigration.

The notion of transmigration is a controversial issue in the Enneads ${ }^{2}$ and an issue of dispute for later Neoplatonists ${ }^{3}$. Modern scholars have taken different approaches: whereas Inge ${ }^{4}$, Pistorius ${ }^{5}$ and Smith $^{6}$ minimize the importance of transmigration in the Enneads, Rich $^{7}$, Rist $^{8}$, Blumenthal ${ }^{9}$ and Armstrong ${ }^{10}$ maintain

\footnotetext{
${ }^{1}$ I am thankful to Andrew Smith, Rosemary Wright, Leo Catana and the members of the Center for Neoplatonic Virtue Ethics at the University of Copenhagen for their invaluable comments and suggestions.

${ }^{2}$ See Enneads i 1.11-12; ii 9.6.10-28; iii 4.2; iv 3.9; iv 7.14.1-8.

${ }^{3}$ For the problem of transmigration in Platonism and Neoplatonism see Dörrie 1957, Smith 1984 and 1987; see also Wallis 1995, 113. For a recent account on Platonism and transmigration see Leftow 2011, 25 ff.

${ }^{4}$ Inge 1929, 33-34 suggests that Plotinus' doctrine of transmigration should not be taken seriously and literally in scientific terms.

${ }^{5}$ Pistorius 1952, 98 maintains that transmigration is an ancient doctrine that Plotinus just uses in his work without further significance.

${ }^{6}$ Smith 1984 states that the doctrine of transmigration does not seem to have greatly worried Plotinus. Smith appropriately argues that transmigration appears to be a serious issue for consideration in Porphyry, while Proclus seems to be the first Neoplatonist to find a solution in a compromise way.

${ }^{7}$ Rich 1957 provides the first complete analysis of the problem of transmigration by refuting Inge 1929 and Pistorius 1952 on the insignificance of transmigration in the Enneads. He argues that Plotinus' believed in transmigration literally and not merely as a metaphor or myth.
} 
the view that Plotinus assigned serious significance to it. In this paper, it is suggested that Plotinus' account of transmigration should be reconsidered in the light of his dual theory of the soul ${ }^{11}$. After some preliminary remarks on the terminology and the philosophical sources of transmigration in the Enneads (Section 1), it is argued that since the higher intelligible part of the soul remains impassive and aloft, transmigration involves only the lower perceptible part of the soul that is related to the compound living bodies (Section 2). It is implied that Plotinus' theory of transmigration aims also to highlight the virtuous life of the wise soul. The noble soul focuses on its higher intelligible self in constant contemplation of the Forms without being affected by its lower perceptible self and therefore any kind of transmigration (Section 3).

The term $\mu \varepsilon \tau \varepsilon \mu \psi v i \chi \omega \sigma ı \varsigma$ does not appear in the Enneads. Plotinus uses the

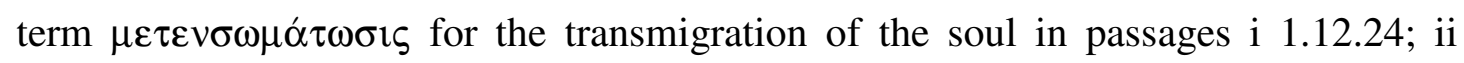

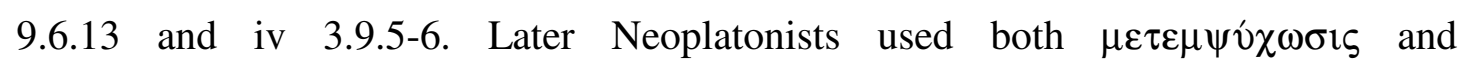
$\mu \varepsilon \tau \varepsilon v \sigma \omega \mu \alpha \dot{\alpha} \tau \omega \sigma \iota \varsigma$ for their relevant accounts of transmigration, particularly in relation to the soul's destiny after death and the question of transmigration of human souls

\footnotetext{
${ }^{8}$ Rist 1963, 227.

${ }^{9}$ Blumenthal 1966, 79.

${ }^{10}$ Armstrong 1967, 146-147 notes (on Ennead iii 4) that Plotinus follows Plato's doctrine of transmigration in Phaedo (81e-82b), Republic X and Timaeus 91-92 and "there is no doubt that he took Plato's statement about animal reincarnation literally and seriously".

${ }^{11}$ As 'dual theory of the soul' I refer to Plotinus' two-part theory of the soul (= higher intelligible part related to Intellect and the lower perceptible part related to the bodies). For the dual theory of the soul and its relation to dual selfhood in the Enneads see Stern-Gillet 2010; see also Remes 2007, 23-59. It has to be noted that in this paper Plotinus' dual soul is not considered in terms of mind-body Cartesian type dualism but in terms of dual-aspect monism which conceives the soul as a unified and homogenous being consisted of two interrelated aspects (= higher and lower). For the dual aspect theory and its relation to monistic metaphysics see Stubenberg 2010. For a general survey of dualistic and monistic interpretations of the soul in Plotinus see Helleman-Elgersma 1980, $89 \mathrm{ff}$.
} 
into animals. ${ }^{12}$ Whereas $\mu \varepsilon \tau \varepsilon \mu \psi v ́ \chi \omega \sigma ı \varsigma$ emphasizes transition at the level of the soul (i.e. the soul incarnates into a new body), the term $\mu \varepsilon \tau \varepsilon v \sigma \omega \mu \alpha ́ \tau \omega \sigma \iota \varsigma$ emphasizes transition at the level of the body (i.e. the soul moves and animates different bodies).

The question of transmigration is traced back to Plato ${ }^{13}$ and some pre-Platonic accounts of the soul, particularly from the early Pythagoreans and Empedocles. ${ }^{14}$ As Plotinus himself states (vi 4.16.4) in a discussion of the soul's "entries into the bodies of other animals" ( views from those who in ancient times have philosophized best about the soul; and it is proper to try to show that our present discourse is in agreement, or at least not in disagreement, with them" (vi 4.16.4-7). According to Armstrong, this is "a very firm statement of the traditionalism of Plotinus; the ancient philosophers are of course Plato and, secondarily, the Pythagoreans". ${ }^{15}$ However, Plotinus' expression $\pi \alpha$ ' $\lambda \alpha \iota$

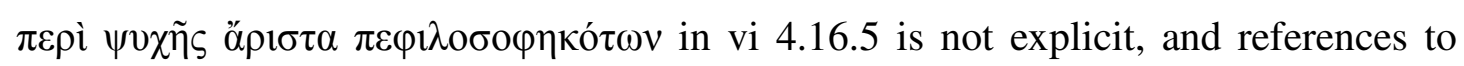
other ancient philosophers should not be excluded.

The case of Ennead iii 4.2.16-30 is relevant for possible Platonic and prePlatonic evidences concerning transmigration in Plotinus:

Those, then, who guarded the man in them, become men again. Those who lived by sense alone become animals; but if their sense-perceptions have been accompanied by passionate temper they become wild animals, and the difference in temper in them makes the differences between the animals of this kind; those whose sense-perceptions went with desires of the flesh and the delight of the desiring part of the soul become lustful and gluttonous animals. But if they did not even live by sense along with their desires but coupled them with dullness of perception, they even turn into plants; for it was this, the growth-principle which worked in

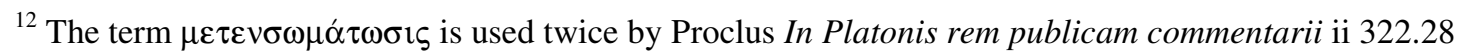
and In Platonis Timaeum commentaria i 113.3. The term $\mu \varepsilon \tau \varepsilon \mu \psi v ́ \chi \omega \sigma 1 \varsigma$ is used by Porphyry (De abstinentia iv 16.15), Iamblichus (Theologoumena arithmeticae 52.12), Proclus (In Platonis rem publicam commentarii ii 340.23) and Damascius (In Phaedonem 335.1); see Smith 1984.

${ }^{13}$ The term $\mu \varepsilon \tau \varepsilon \mu \psi v ́ \chi \omega \sigma \mathrm{s}$ is not found in Plato's works. Olympiodorus, In Platonis Phaedonem commentaria 9.6 offers a comparison between the terms $\mu \varepsilon \tau \varepsilon v \sigma \omega \mu \alpha \dot{\alpha} \tau \omega \sigma \iota \varsigma$ and $\mu \varepsilon \tau \varepsilon \mu \psi v ́ \chi \omega \sigma \imath \varsigma$ on the soul and the animation of the bodies with reference to Plato's Phaedo 87b2-88b8. See Westernik 2009, 134.

${ }^{14}$ See Armstrong 1967, vol. III, 146-147, n. 1 and Kalligas 2004, 390.

15 Armstrong 1988, 321 (on Ennead vi 4.16); for Plotinus and the Pythagorean doctrine of transmigration see also Luchte 2009. Luchte in chapter 9 discusses the doctrine of transmigration in relation to the noetic ascent of the soul towards the One.
} 
them, alone or predominantly, and they were taking care to turn themselves into trees. Those who loved music but were in other ways respectable turn into song-birds; kings who ruled stupidly into eagles, if they had no other vices; astronomers who were always raising themselves to the sky without philosophic reflection turn into birds which fly high. The man who practiced community virtue becomes a man again; but one who has a lesser share of it a creature that lives in community, a bee or something of the sort. [iii 4.2.16-30; trans. Armstrong]

This passage is regarded as an indirect allusion to Plato's account of transmigration found in the Phaedo (81e-82b), the Republic (620) and the Timaeus (91d-92c). ${ }^{16}$ As Rich observes, Plotinus adopts the same playful tone and vocabulary used by Plato in the Phaedo for the transmigration of the soul into animal bodies. ${ }^{17}$ However, Plotinus seems to accept the transmigration of some form of soul not only to humans and animals but also to insects and plants. This version of transmigration is found in Empedocles ${ }^{18}$ and it has been suggested that iii 4.2.16-30 alludes to Empedocles' DK fragments B117 and B127. ${ }^{19}$ In addition, Empedocles' fragment $\mathrm{B} 115$ on the destiny of $\delta \alpha i \mu \omega v^{20}$ is relevant to Plotinus' account of transmigration in iii 4.2.16-30, and particularly his treatment of the soul as $\delta \alpha i ́ \mu \omega \mathrm{v}$ in iii 4.3. Empedocles' fragment B117 is frequently quoted in subsequent philosophical discussions on the possibility of the human soul's transmigration into other forms of life $^{21}$, as well as in the context of the problem of justice and impiety found in fragment $\mathrm{B} 137^{22}$. Empedocles' view of transmigration is also related to the early

\footnotetext{
${ }^{16}$ See Kalligas 2004, 390, and his comment on iii 4.2.16-30.

${ }^{17}$ See Rich 1957, 232, n. 3.

${ }^{18}$ Empedocles considers his own life-history as one of transmigration into various forms, including animals and plants. See the introduction of Inwood 2001, 55-68.

${ }^{19}$ See Armstrong 1967, 146-147, n. 1 on Ennead iii 4.2 and Kalligas ibid.

${ }^{20}$ Empedocles describes the soul as a divine spirit ( $\left.\delta \alpha i \mu \omega v\right)$ which descends into the material world, passing through a number of lives in different elements as different kinds of mortal beings by following the divine law of necessity. See Wright 1981, 69-76; and also Inwood 2001, 86-90.

${ }^{21}$ Hippolytus Refutatio 1.3 (A31) uses the term $\mu \varepsilon \tau \varepsilon v \sigma \omega \mu \alpha \dot{\tau} \tau \sigma \tau \varsigma$, the same word used by Plotinus, just before quoting Empedocles' fragment B117. Aelian On Animals 12.7 (B127) refers to Empedocles and the transmigration of humans to animals. See Wright 1981, 275-276 and 290-291; Roussos 2007, 244; Inwood 2001, 151.

${ }^{22}$ Sextus, in Adversus Mathematicos 9.126-130, relates $\mu \varepsilon \tau \varepsilon v \sigma \omega \mu \alpha \dot{\alpha} \omega \sigma \iota \varsigma$ to Empedocles and the Pythagoreans = fragment B137. See Wright 1981, 286-287 and Inwood 2001, 147-148.
} 
Pythagoreans, and Porphyry testifies (Vita Pythagorae 19) that Pythagoras was the first philosopher to introduce the doctrine of transmigration into Greece. ${ }^{23}$ The initial Pythagorean notion of transmigration is based on the conflict between body and soul, and it is further related to Orphic doctrines according to which the body is viewed as the 'tomb' or 'prison' of the soul (Plato Cratylus 400c). For the early Pythagoreans, it is according to one's present deeds that the soul changes into different life forms, and only the 'noble' souls are released from the suffering of transmigration. ${ }^{24}$ Likewise, Empedocles stresses the 'decree' of the soul being born in different elements as different kinds of lives (B115). Empedocles considers the descent of the $\delta \alpha i$ í $\omega \mathrm{v}$ as a decline, and the embodied soul as "clothed in an unfamiliar garment of flesh" (B126): mortals are "poor, unhappy creatures", born from strife and lamentation (B124). The life in the body is $v \pi^{\prime}$ ö $v \tau \rho o v$ ító $\sigma \tau \varepsilon \gamma o v$ (B120), and it is significant that the source of this particular fragment is Plotinus' disciple Porphyry (De Antro Nympharum 8.14), who also relates Empedocles to the Pythagoreans. ${ }^{25}$

In Ennead iv 8 On the Descent of the Soul into the Bodies Plotinus is aware of

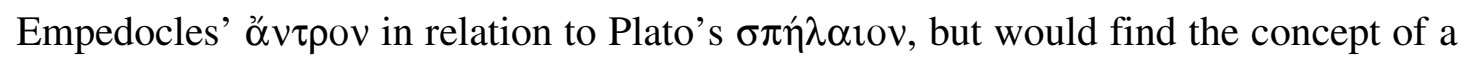
fallen soul that descends into the body unacceptable. In iv 8.1.17-23, Plotinus refers to Empedocles and the 'riddling' accounts of the Pythagoreans, but he also distances Plato, Heraclitus and Empedocles (iv.8.5) ${ }^{26}$ from the general spirit of conflict in the Pythagorean body-soul dualism and eschatology. ${ }^{27}$ Plotinus' reply to the Pythagorean body-soul dualism is based on the ontological unity of his own dual theory of the soul, and the homogeneity between the higher intelligible part of the soul and the lower perceptible part of the soul related to the living bodies. Plotinus' dual theory of the

\footnotetext{
${ }^{23}$ See Stamatellos 2012, 55-57.

${ }^{24}$ For the doctrine of transmigration in Pythagoras and the early Pythagoreans see Luchte 2009.

${ }^{25}$ See Roussos 2007, 240-241.

${ }^{26}$ Plotinus' interpretation of Empedocles (particularly B115) is different from that of Simplicius, In Physica IX.159.9. Plotinus interprets Empedocles not as a Pythagorean dualist but as a pre-Platonist who supports the unity, intelligibility and morality of the soul in the image of $\delta \alpha i$ í $\omega \mathrm{v}$.

${ }^{27}$ See Stamatellos 2007, 166-171.
} 
soul explains his use of transmigration in the Enneads and it is discussed in the next section.

In Ennead iv 8 Plotinus denies the descend of the soul into the bodies. ${ }^{28} \mathrm{He}$ considers, or even reconsiders, the descent of the soul not as a fall but as a kind of spiritual mission necessary for self-realisation, and its return to the divine as gained through self-knowledge and contemplation. The soul as a whole is described in terms of ontological unity and homogeneity ${ }^{29}$ : as a single intelligible source that animates any human, animal or plant form. ${ }^{30}$ The soul is conceived as amphibian, living a 'double life' (iv 8.4.19) between the intelligible and the perceptible world (iv 8.8). ${ }^{31}$ The psyche has a 'double nature', partly intelligible and partly perceptible (iv 8.7); and so it is able to recognize and participate in both the world of the eternal Forms and the world of temporal becoming. Plotinus divides (theoretically but not ontologically) the hypostasis of soul into world soul and individual souls (iv 8.2). Whereas the individual soul governs with difficulty and struggle the lower in purity and unity perceptible body, the world soul cares and directs the higher universal body with pure intelligible power. The world soul animates the corporeal bodies with its logoi (iii 6.19.26-29; iv 3.10.35-42; v 1.6) and illuminates with its intelligible light the perceptible universe (iii 8.4).

Thus, for Plotinus, every soul has something of what is 'below' in the direction of the body (= the lower perceptible part) and of what is 'above' (= the

\footnotetext{
${ }^{28}$ See Kalligas 2009, 614-618.

${ }^{29}$ Plotinus' theory of soul is present throughout the nine treatises of Ennead IV; for a general account on the Plotinian soul see the influential study of Blumenthal 1971.

${ }^{30}$ See Blumenthal 1971, 14 f., 29, 73-74.

${ }^{31}$ For soul as principle of mediation between the intelligible and the perceptible world see Rangos 1999.
} 
higher intelligible part) in the contemplation of Intellect (iv 8.8.11-13). ${ }^{32}$ In this context Plotinus' psychology is marked by his dual selfhood theory. ${ }^{33}$ He maintains two kinds of selves: (a) the higher self related to the higher part of the soul and the intelligible world and (b) the composite soul-body selves related to the lower part of the soul and perceptible world. ${ }^{34}$ However, the distinction between the higher intelligible self and the lower perceptible self in Plotinus should not be conceived in terms of a mind-body Cartesian type dualism; i.e. the soul's higher self (=related to mind) and the lower self (= related to the body) are not two distinct ontological states or parts. Plotinus' dual theory of the soul should be approached in terms of a dualaspect monism ${ }^{35}$, which supports the ontological unity and homogeneity of the one psyche . The higher and lower parts of the soul are two aspects of the same and homogenous soul. In the light of Plotinus' ontological priority of the soul and his dual aspect monistic psychology, the soul is defined as not present in the body but the body as present in the soul (iv 3.22-23) ${ }^{36}$; it is the body that is ensouled and not the soul that is embodied. ${ }^{37}$ Hence Plotinus considers the perceptible bodies as illuminations ( $\dot{\varepsilon} \lambda \lambda \alpha \dot{\alpha} \mu \psi \varepsilon 1 \varsigma$ ) of the intelligible entities upon matter (vi 7.7.12). The perceptible bodies are composite entities of matter and form (ii 4.2.15), but they are still mere representations - "images drawn on the shadow" (vi 3.8.35-36, III 6.14.25). The higher part of the soul is not affected by the lower part attached in the bodies (iv 3.12; iii 6.7-13; v 1.9.20-34).

Plotinus' treatment of transmigration as $\mu \varepsilon \tau \varepsilon v \sigma \omega \mu \alpha \dot{\alpha} \omega \sigma i \varsigma$ should be reconsidered in this context of his dual theory of the soul. As Dillon suggests, Plotinus' view of transmigration makes it possible to envisage "a form of the sum-

\footnotetext{
${ }^{32}$ See Blumenthal 1971, 65 ff. See also Remes 2007, 23 ff.

${ }^{33}$ For dual selfhood in Plotinus see Stern-Gillet 2010, 331-337.

${ }^{34}$ See Remes 2007, 23-59.

${ }^{35}$ For the dual aspect theory see Stubenberg 2010, 9.4.

${ }^{36}$ Plotinus seems to follow Plato's Timaeus 34d and 36d; see Kalligas 2009, 407-408.

${ }^{37}$ For this body and soul relation in Plotinus see Clark 1996.
} 
total of individual manifestations of the same soul". ${ }^{38}$ Following this view, Plotinus'

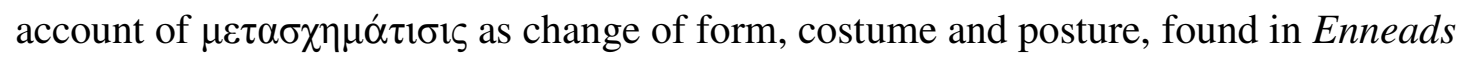

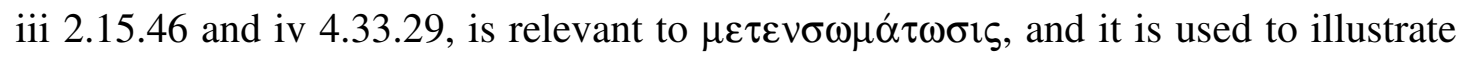
the soul-body relationship. This is justified both at the cosmic and the human level.

At the cosmic level, $\mu \varepsilon \tau \alpha \sigma \chi \eta \mu \alpha \dot{\tau} \tau \sigma ı 1 \varsigma$ refers to the continual change and movement of the celestial bodies within the harmonious cycles of the universe (iv 4.33). Plotinus finds a symbol for the heavenly circuit of the cosmos in the pantomime dance of the divine dancer acting in a rich variety of solo dancemovements. The whole universe "actively lives its own complete life, moving its great parts within itself, and continually rearranging them" ( $\mu \varepsilon \tau \alpha \sigma \chi \eta \mu \alpha \tau i \zeta \zeta o v \tau \alpha \iota ~ \grave{\alpha} \varepsilon i ́) "$ as in the dance of pantomime (25-30). ${ }^{39}$ The celestial arrangements manifest the divine logos: i.e. the movements of the heavenly circuit are transformations caused by the movements of the divine dancer. ${ }^{40}$

At the human level, Plotinus maintains that tragic and cruel moments in life should not be taken seriously, but they should be regarded as incidents in the plot of a play: "we should be spectators of murders, and deaths, and takings and sacking of cities, as if they were on the stages of theaters, all changes of scenery and costume ( $\mu \varepsilon \tau \alpha \sigma \chi \eta \mu \alpha \tau i ́ \sigma \varepsilon 1 \varsigma)$ and acted wailings and weepings" (iii 2.15.43-47). It is not our inner-man (= our higher self) that participates in the 'game of life' but the outer-man (=our lower self), that is, "the outside shadow of man" (47-50). The inner-man remains unaffected by bodily affections and sufferings while the outer-man "has to put off the play-costume in which he is dressed" (55-57). The bodily life of the outer-

\footnotetext{
${ }^{38}$ See Dillon 1992, 198.

${ }^{39}$ See also Ennead iii 2.16; Armstrong 1967, 240 notes that Plotinus' metaphor of the pantomime symbolizes the living and moving harmony of the cosmos corresponding to the Indian divine figure of the dancing Shiva; see also Kalligas 2004, 485-486 on iv 4.33.

${ }^{40}$ Plato at Laws X (903e5) uses $\mu \varepsilon \tau \alpha \sigma \chi \eta \mu \alpha ́ \tau \imath \sigma ı \varsigma$ with reference to cosmos and god: it is related to the god's effortless supervision of the cosmos by 'transforming everything' ( $\left.\mu \varepsilon \tau \alpha \sigma \chi \eta \mu \alpha \tau i \zeta \zeta \omega \nu \tau \alpha \grave{\alpha} \pi \alpha v_{\tau} \alpha\right)$ in

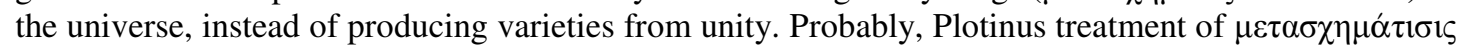
in iv 4 alludes to Plato's Laws.
} 
man is like a role in earthly life, and the changes of forms and costumes in the drama of life are bodily $\mu \varepsilon \tau \alpha \sigma \chi \eta \mu \alpha \tau i ́ \sigma \varepsilon ı \varsigma$ of the soul. ${ }^{41}$

It is noteworthy that the changing-role metaphor was also used by later Neoplatonists such as Iamblichus who claimed that, in transmigration, the human substance remains the same as the actor's human nature, despite the external changes in different roles. ${ }^{42}$ However, the transmigration of the human soul into animal bodies was a controversial issue for later Neoplatonists. On the one hand, Iamblichus and Proclus rejected human transmigration to animals since human and animal souls are essentially different or, as Wallis has stated, "they denied that animals have souls at all in the strict sense of the term" ${ }^{43}$ When the evil man acquires a beast-like character then the sinful human soul is temporarily associated with an animal body or form. ${ }^{44}$ On the other hand, Porphyry seems to follow Plotinus' transmigration of the human soul into animal bodies in so far as both human souls and animal souls are derived from the same intelligible source. ${ }^{45}$

Plotinus' treatment of transmigration diminishes the ontological differences between psychic classes and hierarchies. ${ }^{46}$ Whereas for Plotinus transmigration is based on the non-hierarchical unity and homogeneity of the soul, later Neoplatonists refuted transmigration through greater emphasis on a hierarchical ontology, in which the existence of the human soul possesses a higher rank than that of other animals. Since, for Plotinus, the soul is a homogenous and single intelligible source of life, all

\footnotetext{
${ }^{41}$ The term $\mu \varepsilon \tau \alpha \sigma \chi \eta \mu \alpha \tau \zeta \zeta o \mu \varepsilon ́ v \alpha \varsigma$ is also used by Plutarch (De sera numinis vindicta 567e) for the

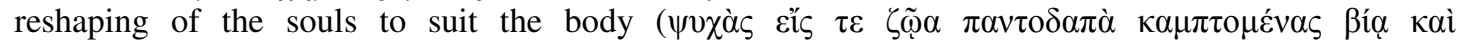
$\mu \varepsilon \tau \alpha \sigma \chi \eta \mu \alpha \tau ı \zeta o \mu \varepsilon ́ v \alpha \varsigma)$; see the analysis of Smith 1984, 277.

${ }^{42}$ Smith ibid. 280-281.

${ }^{43}$ See Wallis 1995, 120. Wallis 1995, 113 observes that Augustine and Aeneas of Gaza rejected animal transmigration in the light of Iamblichus' doctrine of transmigration.

${ }^{44}$ The Chaldaean Oracles rejected animal transmigration, Proclus In Remp. ii $336.27 \mathrm{ff}$.

${ }^{45}$ As Smith 1984 observes, while Augustine states explicitly that Porphyry denied transmigration, Porphyry texts show that he used transmigration both in literal and metaphorical terms. For an evaluation of eschatology in Porphyry and Plotinus see Smith 1974, 69 ff.

${ }^{46}$ See Wallis 1995, 113 and 120.
} 
transmigrations into various life forms are possible, and so all ensouled bodies are rational and immortal:

As for the souls of other living things, those of them which have been failures and come into animal bodies must also be immortal. But if there is another [non-human] kind of soul, it cannot come from anywhere else than from the nature which lives, and this too must really exist and be the cause of life in the living things, and the same is certainly true of the soul in plants: for they all started from the same origin and have their own life and they too are bodiless and without parts and substances. [iv 7.14.1-8; trans. Armstrong]

However, the making of the lower animals is not against the nature of the soul (vi 7.7). If the soul has the opportunity, it makes what is finer - like a craftsman who knows how to make various forms but selects a particular one in accordance with the requirements of the specific material (1-8).

For what is there to prevent the power of the Soul of the All from drawing a preliminary outline, since it is the universal forming principle $(\log o s)$, even before the soul-powers come from it, and this preliminary outline being like illuminations running on before matter, and the soul which carries out the work following traces of this kind and making by articulating the traces part by part, and each individual soul becoming this to which it came by figuring itself, as the dancer does to the dramatic part given him? [vi 7.7.8-15; trans. Armstrong]

Plotinus' image of the dancer performing a dramatic part in this passage (

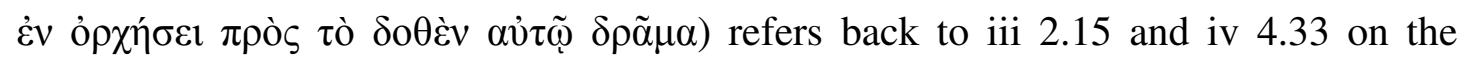
$\mu \varepsilon \tau \alpha \sigma \chi \eta \mu \alpha \tau i ́ \sigma \varepsilon ı \varsigma$ of the soul.

Thus Plotinus' notion of transmigration as $\mu \varepsilon \tau \varepsilon v \sigma \omega \mu \alpha ́ \alpha \omega \sigma \iota \varsigma$ should be understood as involving the lower perceptible part of the soul. Transmigration should be considered as an illumination ( $(\xi \lambda \lambda \alpha \mu \psi 1 \varsigma)$ of the world soul directed to what is

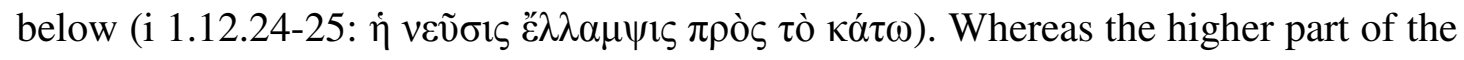
soul, which is identified with the world soul, constantly contemplates the intelligible world, the lower part of the soul, unceasingly animates the perceptible bodies. Therefore, since all perceptible bodies are illuminations of the world soul, transmigration is related to the lower perceptible part for soul. Transmigration should be conceived as a transient $\check{\varepsilon} \lambda \lambda \alpha \mu \psi 1 \varsigma$ of the world soul's higher intelligible light transmitted into different bodily forms, but without affecting the unity and 
homogeneity of the soul as an organic whole. Plotinus' ontology of transmigration has also some ethical objectives that are discussed in the next section.

In Ennead iv 3.9.14-16, Plotinus considers the body's ensoulment not for literal but for didactic purposes. He states that with regard to the world soul the terms "entry"

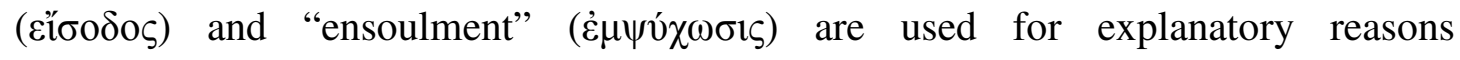

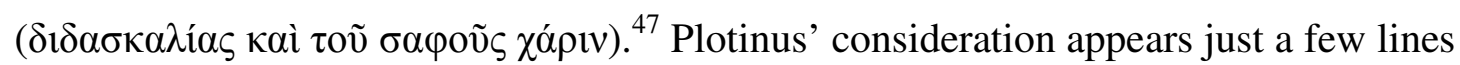
after his discussion on $\mu \varepsilon \tau \varepsilon v \sigma \omega \mu \alpha \dot{\tau} \omega \sigma \mathrm{\iota} \varsigma$ and his aporia about the soul's entering into the body. The didactics of transmigration may be also observed in Ennead in iii

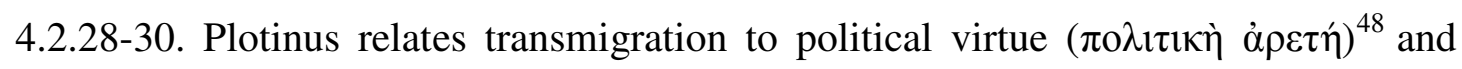
distinguishes between different degrees of involvement in the community: active involvement (man) and lesser involvement (animal or insect). He maintains that the man who is actively involved in the community and practices political virtue becomes a man again, while the one who lives a life with a lesser share in community becomes an animal or insect of lower sort. Whereas the wicked soul weights down by the force of its bad spirit, the wise soul ascends to the higher intelligible world through the power of virtue.

For Plotinus, virtue purifies and raises the soul from the perceptible world of temporal becoming to the divine world of true beauty and intelligence (i 6.6). The wise man $(\sigma \pi \mathrm{ov \delta} \delta \tilde{i n o})^{49}$ ascends to the life of Intellect by the force of his godlike spirit ( $\left.\delta \alpha{ }^{\prime} \mu \omega v\right)$ (iii 4.3). Each soul is an "intelligible universe" (iii 4.3) and our "allotted guardian spirit" is not 'allotted' by an external necessity or chance but is to be interpreted in terms of our own moral and intelligible principles according to

\footnotetext{
${ }^{47}$ See Kalligas 2009, 372-373; see also Enneads iii 5.9.24-29 and vi 7.35.33-34.

${ }^{48}$ For Plotinus' notion of virtue see Enneads i 2 On Virtues and i 4 On Well-Being. See also Ennead i 3 On Dialectic. For Plotinus' virtue ethics see Plass 1982; Kalligas 1984 introductory notes on Ennead i 2; Dillon 1996, Smith 1999, Remes 2006 and Stern-Gillet 2009.

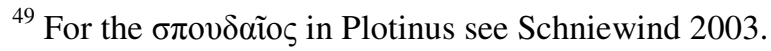


which we have chosen to live (iii 4.4-6). The $\delta \alpha i ́ \mu \omega v$ of the $\sigma \pi$ ov $\delta$ ĩos is a god who chooses to follow the life of virtue that raises the soul to the level of Intellect and purifies our lives (iii 4.5). The $\sigma \pi 00 \delta \alpha$ ĩo $\varsigma$ is the true inner man, our higher intelligible self that possesses "the virtues which belong to the sphere of intellect and have their seat actually in the separate soul, separate and separable even while it is still here below" (i 1.10.7-10). The wise and noble soul aims to live the eternal life of Intellect, the life of the higher part of the soul purely contemplating the divine reality of Nous. The real virtue of the $\sigma \pi 0 v \delta \alpha i ̃ s$ is to be aware of the perfection, self-sufficiency and completeness of Intellect: to contemplate the intelligible world where the soul is truly purified (i 2.4).

Virtue is to be attained not by having intellect but by being intellect in selfthinking eudaimonia (i 4.4). The noble soul of the $\sigma \pi$ ovdoĩos returns to its higher intelligible self through self-contemplation in likeness of Intellect's eudaimonia. Plotinus vividly states that we have to become what we are; i.e. to "sculpt the statue of ourselves" and to care for our soul in a continuous process of self-perfection through the purification of virtue ${ }^{50}$ (i 6.9). The virtue of the wise that leads to eudaimonia is to exercise the higher activity of the soul's intelligible self (i 2.6-7). The $\sigma \pi$ ov $\delta$ ĩos focuses on the higher intelligible part of the soul identified with the world soul; i.e. the higher part of the soul that is neither affected by the suffering and misfortune of the animated bodies (i 4.5-8) nor influenced in any way by the life of the perceptible world (i 4.9).

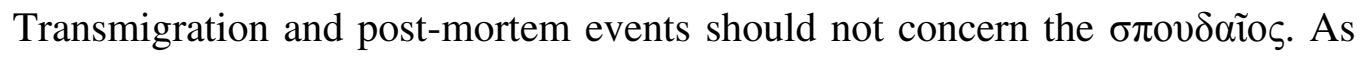
Plotinus clarifies in i 1.11-12 that world soul is sinless and not involved in transmigration:

And how does the living thing include brute animals? If, as is said, there are sinful human souls in them, the separate part of the soul does not come to belong to the beasts but is there without being there for them; their consciousness includes the image of soul and the body: a beast is then a qualified body made, as we may say, by an image of soul. But if a human soul

\footnotetext{
${ }^{50}$ For self-perfection in Plotinus and its relation to dual selfhood see Stern-Gillet 2009.
} 
has not entered the beast it becomes a living being of such and such a kind by an illumination from the world soul. [i 1.11.8-15; trans. Armstrong modified]

As intelligible and divine logos, the world soul has no sins (i 1.11.8-15; 12.1-4) and, therefore, it cannot be judged or punished in Hades nor transmigrated by passing

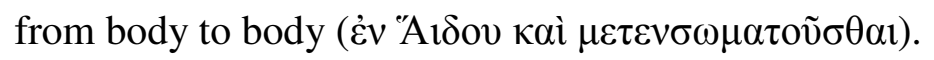

But if the soul is sinless, how is it judged? This line of thought disagrees with all arguments which maintain that the soul sins and acts rightly and undergoes punishment, punishment in Hades, and that it transmigrates. [i 1.12.1-4; trans. Armstrong modified]

As Plotinus further explains in Ennead ii 9, punishment in Hades is a part of Plato's eschatology that the Gnostics ${ }^{51}$ plagiarize and misinterpret: "for the judgments too, and the rivers in Hades and the reincarnations come from Plato" (ii 9.6.12-14). ${ }^{52}$ It is only the lower part of the soul - an image of the soul - that transmigrates. The world soul or the higher part of the soul remains sinless and unaffected by bodily sufferings and concerns. Plotinus illustrates his position with the mythical figure of Heracles who is both a shade in Hades and among the gods: "Heracles had this active virtue and in view of his noble character was deemed worthy to be called a god because he was an active and not a contemplative person (in which case he would be altogether in that intelligible world), he is above, but there is also still a part of him below" (i 1.12.35-39).

Thus transmigrations and the punishments in Hades should not be conceived as involving the soul's higher intelligible part but they should be regarded as relevant only to the soul's lower perceptible part that is related to the body. The higher part of the soul, the intelligible part on which the $\sigma \pi 0 v \delta \alpha$ ios constantly attends and contemplates, remains undescended and uninvolved in transmigration. The higher part of the soul is firmly rooted and established in the divine world of the Forms. The

\footnotetext{
${ }^{51}$ Plotinus refers mainly to Plato's mythical narration of after-life in the Phaedo $111 \mathrm{~d}$ ff. For Hades in Plotinus and Porphyry as an earthly body see Smith 1984, $278 \mathrm{ff}$.

${ }^{52}$ Plotinus criticizes the immoral doctrines of the Gnostics at ii 9.15. The Gnostics exclude virtue from human life: they do not clarify what virtue is nor do they explain to us how the divine world will be attained without virtue (15.26-40). For Plotinus and the Gnostics see Puech 1960, 159-190; Wallis 1995, 12-13 and Kalligas 1997, 327 ff. On ii 9.15 see Kalligas 1997, 376-378.
} 
cathartic power of virtue enables the wise soul to recognize both itself and its divine origins as well as to guard itself against the blows of fortune (ii.9.18.26-30). The $\sigma \pi$ ov $\alpha$ ĩos follows the higher life of virtue; the life of the noble souls that belong to the intelligible realm of the Forms; a life in likeness to the perfect, self-sufficient and self-determined divine reality of Nous.

Concluding: Plotinus' treatment of $\mu \varepsilon \tau \varepsilon v \sigma \omega \mu \alpha$ ó $\tau \omega \sigma \imath \varsigma$ is consistent with his dual theory of the soul. In the Enneads transmigration concerns only the lower perceptible part of the soul that is attached to the corporeal bodies. The higher part remains aloft in the intelligible world. Since transmigration is related to the lower perceptible part of the soul, therefore transmigration becomes irrelevant to the higher intelligible part of the soul. After death the perceptible part of the soul either ceases to exist or is reabsorbed into the world soul. Plotinus praises the excellence of the wise soul that constantly contemplates through the life of virtue its higher intelligible self and transcends its lower perceptible self. Virtue frees and purifies the noble souls from the perceptible realm so that the wise soul becomes self-sufficient and selfperfected without being concerned with any kind of transmigration.

Giannis Stamatellos

New York College (Athens) - Empire State College - SUNY

\section{Bibliography}

Armstrong, A. H. 1966-1988. Plotinus. 7 vols. Loeb Classical Library. Cambridge: Harvard University Press.

Blumenthal H. J. 1966. 'Did Plotinus Believe in Ideas of Individuals?' Phronesis 11, 1: 61-80.

DOI: $10.1163 / 156852866$ X00139. 
Blumenthal, H. J. 1971 Plotinus' Psychology. The Hague: Martinus Nijhorf.

Clark, S. R. L. 1996. 'Plotinus: Body and Soul' in L. P. Gerson ed. The Cambridge companion to Plotinus. Cambridge: Cambridge University Press: 275-291. DOI: 10.1017/CCOL0521470935.012

DK = Diels, H. 1951-2. Die Fragmente der Vorsokratiker. 6th ed. Revised with additions and index by W. Kranz, Berlin: Weidmann.

Dillon, J. M. 1992. 'Plotinus at Work on Platonism' Greece \& Rome 39, 2: 189-204.

DOI: $10.1017 / \mathrm{S} 0017383500024177$.

Dillon, J. M. 1996. 'An ethic for the late antique sage' in L. P. Gerson ed. The Cambridge companion to Plotinus. Cambridge: Cambridge University Press: 315-335. DOI:10.1017/CCOL0521470935.014.

Dörrie, H. 1957. 'Kontroversen um die Seelenwanderung im kaiserzeitlichen Platonismus' Hermes 85: 414-435.

Helleman-Elgersma, W. 1980 Soul-Sisters. A Commentary on Enneads IV, 3 (27) 1-8 of Plotinus. Amsterdam: Rodopi.

Henry, P. and H. R. Schwyzer. 1964-1982. Plotini Opera. editio minor. Oxford: Oxford University Press.

Inge, W. R. 1929. The Philosophy of Plotinus. vol. II. London: Longmans, Green \& Co.

Inwood, B. 2001. The Poem of Empedocles: A Text with an Introduction. Revised Edition. Toronto: University of Toronto Press.

Kalligas, P. 1994. Plotinus' Ennead I: Ancient Greek text, translation and commentary. Athens: Centre of Edition of Ancient Greek Authors.

Kalligas, P. 1997. Plotinus Ennead II: Ancient Greek text, translation and commentary. Athens: Centre of Edition of Ancient Greek Authors.

Kalligas, P. 2004. Plotinus Ennead III: Ancient Greek text, translation and commentary. Athens: Centre of Edition of Ancient Greek Authors.

Kalligas, P. 2009. Plotinus Ennead IV: Ancient Greek text, translation and commentary. Athens: Centre of Edition of Ancient Greek Authors.

Leftow, B. 2011. 'The humanity of God' 20-44 in Anna Marmodoro and Jonathan Hill edd. The Metaphysics of the Incarnation. Oxford: Oxford University Press. DOI:10.1093/acprof:oso/9780199583164.003.0002.

Luchte, J. 2009. Pythagoras and the doctrine of transmigration: wandering souls. Continuum.

Pistorius, P. V. 1952. Plotinus and Neoplatonism: An Introductory Study. Cambridge: Bowes \& Bowes.

Plass, P. 1982. 'Plotinus' ethical theory' Illinois Classical Studies 7, 2: 241-259.

Puech, H.-Ch. 1960. 'Plotin et les Gnostiques' in Les sources de Plotin. Entretiens sur l'antiquité class., 5, Vandoeuvres-Genève, Fond. Hardt: 159-190.

Rangos, S. 1999 'Between Physics and Nous: Logos as Principle of Meditation in Plotinus' Journal of Neoplatonic Studies 7, 2: 1-42.

Remes, P. 2006. 'Plotinus' ethics of disinterested interest' Journal of the History of Philosophy 44: 1-23. DOI: 10.1353/hph.2006.0006. 
Remes, P. 2007 Plotinus on self: the philosophy of the 'We'. Cambridge, New York: Cambridge University Press. DOI: 10.1017/CBO9780511597411.

Rich, A. N. M. 1957. 'Reincarnation in Plotinus' Mnemosyne 10: 232-238. DOI: 10.1163/156852557X00204.

Rist, J. M. 1963 'Forms of Individuals in Plotinus' The Classical Quarterly 13, 2: 223-231. DOI:10.1017/S0009838800001828.

Rist, J. M. 1965. 'Monism. Plotinus and some predecessors' Harvard Studies in Classical Philology 69: 329-344. DOI: 10.2307/310786.

Roussos, E. 2007. Empedocles. Athens: Stigmi.

Smith, A. 1974. Porphyry's Place in the Neoplatonic Tradition. A Study in post-Plotinian Neoplatonism. The Hague: Nijhoff.

Smith, A. 1984. 'Did Porphyry Reject the Transmigration of Human Souls into Animals?' Rheinisches Museum für Philologie Band, Heft I: 276-284.

Smith, A. 1987. 'Porphyrian Studies Since 1913' in Haase, W. Aufstieg und Niedergang der Römischen Welt II.36.2, Berlin: Walter de Gruyter: 717-773.

Smith, A. 1999. 'The significance of practical ethics for Plotinus' in Cleary, J. J. ed. Traditions of Platonism: Essays in Honor of John Dillon. Aldershot: 227-236.

Stamatellos, G. 2007 Plotinus and the Presocratics. Albany: SUNY Press.

Stamatellos, G. 2012 Introduction to Presocratics: A Thematic Approach to Early Greek Philosophy with Key Readings. Wiley-Blackwell.

Schniewind, A. (2003) L'Éthique du Sage chez Plotin. Le paradigme du spoudaios. Paris: Librairie Philosophique J. Vrin.

Stern-Gillet, S. 2009. 'Dual Selfhood and Self-Perfection in the Enneads'. Epoché 13, 2: 331345. DOI: 10.5840/epoche200913210.

Stubenberg, L. 2010. 'Neutral Monism' in: The Stanford Encyclopedia of Philosophy (Spring 2010 ed.), $\mathrm{URL}=<$ http://plato.stanford.edu/archives/spr2010/entries/neutral-monism/>.

Vogel (De), C. J. 1969. 'The monism of Plotinus'. Philosophia: Studies in Greek Philosophy 1: 399-416.

Wallis, R. T. 1995 Neoplatonism. London: Duckworth.

Westerink, L.G. 2009 The Greek commentaries on Plato's Phaedo: Olympiodorus, vol. 1, Prometheus Trust.

Wright, M. R. 1981. Empedocles: The Extant Fragments. New Haven: Yale University Press. 